\title{
Aplikasi Formula Cair Pseudomonas fluorescens P60 untuk Menekan Penyakit Virus Cabai Merah
}

\section{Liquid Formula Application of Pseudomonas fluorescens P60 for Suppressing Viral Disease of Chili Pepper}

\author{
Loekas Soesanto*, Endang Mugiastuti, Ruth Feti Rahayuniati \\ Universitas Jenderal Soedirman, Purwokerto 5123
}

\begin{abstract}
ABSTRAK
Penyakit virus cabai masih sukar diatasi sehingga perlu dikaji penggunaan Pseudomonas fluorescens P60. Penelitian ini bertujuan menentukan formula cair. P. fluorescens P60 terhadap penyakit virus pada tanaman cabai serta pengaruhnya terhadap pertumbuhan dan hasil tanaman cabai merah. Penelitian disusun menggunakan rancangan acak kelompok dengan 7 perlakuan dan 4 ulangan, meliputi kontrol, aplikasi insektisida, penyiraman bibit dan penyemprotan P. fluorescens P60 sebanyak 1, 2, 3, 5, dan 7 kali. Hasil penelitian menunjukkan bahwa penyiraman dan penyemprotan P. fluorescens P60 5 kali mampu menekan penyakit virus pada tanaman cabai merah dengan menurunkan intensitas penyakit sebesar $73.37 \%$, meningkatkan kepadatan populasi akhir $P$. fluorescens P60 sebanyak $9.50 \times 10^{11}$ dan kandungan fenol (saponin, tanin, dan glikosida). Penyiraman dan penyemprotan P. fluorescens P60 5 kali mampu meningkatkan pertumbuhan dan hasil tanaman cabai merah dengan meningkatkan tinggi tanaman $23.7 \%$, panjang akar $6.44 \%$, bobot kering tanaman $66.68 \%$, bobot kering akar $23.59 \%$, dan bobot hasil $53.157 \%$.
\end{abstract}

Kata kunci: bakteri antagonis, ketahanan sistemik, senyawa fenol

\begin{abstract}
Viral diseases of chilli pepper are difficult to control, therefore the use of Pseudomonas fluorescens P60 should be evaluated. The aims of this research were to determine the influence of liquid formula of P. fluorescens P60 on virod disease and on growth and yield of chili pepper. Randomized block design (RBD) experiment was composed of 7 treatments and 4 replicates, i.e., control, insecticide applicaton, P. fluorescens P60 application by seedling drenching and spraying for 1, 2, 3, 5, and 7 times. The result showed that 5 times application of $P$. fluorescens P60 by drenching and spraying was able to suppress viral disease and reduce disease intensity by to $73.37 \%$, increasing density level of $P$. fluorescens P60 to $9.50 \times 10^{11}$ and increase phenolic compounds (saponin, tannin and glycoside). The same treatment could increase plant height $23.7 \%$, root lenght $6.44 \%$, plant dry weight $66.68 \%$, root dry weight $23.59 \%$, and yield weight $53.16 \%$.
\end{abstract}

Key words: antagonistic bacteria, phenolic compound, sistemic resistance

*Alamat korespondensi: Fakultas Pertanian, Universitas Jenderal Soedirman, Jalan dr. Suparno, Karangwangkal, Purwokerto 5123

Tel: 0281-638791, Faks: 0281-638791, Surel: lukassus26@gmail.com 


\section{PENDAHULUAN}

Produksi cabai merah secara nasional terus mengalami peningkatan. Petani masih kesulitan untuk menjaga produksi cabai merah tetap stabil dikarenakan banyak kendala yang dihadapi pada saat mengelola tanaman cabai, terutama gangguan organisme pengganggu tumbuhan (OPT).

Salah satu OPT penting pada tanaman cabai adalah virus. Virus yang sering menginfeksi tanaman cabai ialah antara lain Tobacco mosaic virus, Geminivirus, Tobacco ratlle virus, Cucumber mosaic virus, Tomato ringspot virus, dan Potato virus $Y$ (Jones 2009). Usaha pengendalian virus pada saat ini masih ditekankan pada penggunaan pestisida sintetik untuk mengendalikan vektor virus. Penggunaan insektisida yang tidak bijaksana menimbulkan banyak masalah, antara lain kesehatan sehingga perlu dilakukan pengendalian alternatif yang efektif dan ramah lingkungan.

Pseudomonas fluorescens P60 merupakan salah satu bakteri antagonis karena memiliki kemampuan mengimbas ketahanan sistemik. P. fluorescens P60 dilaporkan meningkatkan kandungan senyawa fenol tanaman (Wardhana et al. 2009; Soesanto et al. 2010). Formula agens hayati yang baik perlu diteliti karena memegang peranan penting bagi pemasaran.

Penelitian ini bertujuan menentukan formula $P$. fluorescens untuk menekan penyakit virus pada tanaman cabai serta meningkatkan pertumbuhan dan hasil tanaman cabai.

\section{BAHAN DAN METODE}

Penelitian dilaksanakan di lahan percobaan di Desa Ciberem, Kecamatan Sumbang, Kabupaten Banyumas, dengan ketinggian tempat $110 \mathrm{~m}$ di atas permukaan laut.

\section{Penyiapan Isolat}

Isolat $P$. fluorescens P60 koleksi Laboratorium Mikrobiologi, Fakultas Pertanian, Universitas Jenderal Soedirman, Purwokerto disiapkan pada medium cair
King's B dalam labu Erlenmeyer, kemudian diinkubasi selama $2 \times 24$ jam pada suhu kamar dan dikocok (Daiki Orbital Shaker) dengan kecepatan $150 \mathrm{rpm}$.

\section{Penyiapan Formula Cair Pseudomonas fluorescens P60}

Formula cair dibuat dengan merebus $400 \mathrm{~g}$ daging keong dengan $1 \mathrm{~L}$ air dan ditambahkan $2 \mathrm{~g}$ terasi sampai mendidih, kemudian disaring dan kaldunya dimasukkan ke dalam jerigen steril, ditutup rapat, dan disimpan pada suhu kamar sampai dingin (Soesanto et al. 2010). Isolat P. fluorescens P60 (konsentrasi $10^{9}$ upk $\mathrm{mL}^{-1}$ ) dimasukkan ke dalam kaldu keong dan dikocok (Daiki Orbital Shaker) selama 3 hari pada suhu ruang dengan kecepatan $150 \mathrm{rpm}$.

\section{Pengaruh Pemberian Formula Cair $P$. fluorescens P60 terhadap Komponen Patosistem}

Penelitian dirancang menggunakan rancangan acak kelompok nonfaktorial dengan 7 perlakuan dan 4 ulangan. Perlakuan yang dicoba meliputi kontrol, insektisida (bahan aktif Sipermetrin, konsentrasi $20 \mathrm{~mL}$ per 17 $\mathrm{L}$ air), serta penyiraman dan penyemprotan P. fluorescens P60 sebanyak 1, 2, 3, 5, dan 7 kali. Aplikasi P. fuorescens P60 dilakukan dengan interval 1 minggu dengan dosis 20 $\mathrm{mL}_{\text {tanaman }}^{-1}$ (untuk aplikasi 1-3) dan $40 \mathrm{~mL}$ tanaman $^{-1}$ (untuk aplikasi ke 4-7).

Peubah yang diamati meliputi masa inkubasi, intensitas penyakit, kepadatan akhir antagonis dengan metode pengenceran (Elad et al. 1987), tinggi akhir tanaman, panjang akar terpanjang (akhir penelitian), bobot kering akar, bobot hasil, dan analisis senyawa fenol secara kualitatif (Chairul 2003). Perhitungan intensitas penyakit menggunakan rumus:

$$
\mathrm{IP}=\frac{\Sigma(\mathrm{n} \times \mathrm{v})}{\mathrm{N} \times \mathrm{Z}} \times 100 \% \text {, dengan }
$$

IP, intensitas penyakit (\%); n, jumlah tanaman terserang pada tiap kategori; N, jumlah tanaman diamati; $\mathrm{Z}$, nilai kategori serangan patogen; v, nilai setiap kategori serangan patogen. Penilaian gejala penyakit karena virus menggunakan skala (Dolores 1996). 


\section{Analisis Data}

Data dianalisis dengan uji F. Apabila berbeda nyata, dilanjutkan dengan $\mathrm{BNJ}$ pada tingkat kesalahan 5\%. Data kepadatan populasi akhir antagonis dan analisis jaringan dianalisis secara deskriptif.

\section{HASIL}

\section{Formula Cair P. fluorescens P60 terhadap} Komponen Patosistem

Masa inkubasi dari perlakuan aplikasi penyiraman dan penyemprotan $P$. fluorescens P60 cenderung meningkat atau lebih lama munculnya gejala penyakit, terutama aplikasi penyemprotan 5 kali, jika dibandingkan dengan kontrol dan insektisida, dengan perbedaan masing-masing sebesar 9 dan 8 hari atau $25.15 \%$ dan $22.29 \%$ (Tabel 1).

Intensitas penyakit tertinggi terdapat pada petak kontrol, yaitu sebesar 59.32\%. Antarperlakuan penyiraman dan penyemprotan P. fluorescens P60 tidak menunjukkan nilai intensitas yang berbeda, namun kemampuan dalam menekan intensitas penyakit cenderung meningkat seiring dengan meningkatnya frekuensi aplikasi antagonis. Kemampuan penekanan intensitas penyakit ini juga tidak berbeda nyata dengan pemberian insektisida (Tabel 1).

Populasi akhir P. fluorescens P60 menunjukkan peningkatan pada perlakuan penyiraman dan penyemprotan $P$. fluorescens P60 yang lebih sering (Tabel 2)

\section{Formula Cair P. fluorescens P60 terhadap Pertumbuhan dan Hasil}

Analisis data menunjukkan adanya perbedaan nyata antarperlakuan terhadap tinggi tanaman (Tabel 3). Tanaman tertinggi ditunjukkan pada perlakuan penyiraman $P$. fluorescens P60 sebanyak 5 kali, yaitu sebesar $71.12 \mathrm{~cm}$ atau terjadi peningkatan $23.7 \%$ dan berbeda nyata dengan perlakuan kontrol. Pada peubah panjang akar, hasil analisis data menunjukkan tidak adanya perbedaan nyata antarperlakuan. Namun demikian, terdapat kecenderungan meningkatnya frekuensi aplikasi antagonis akan meningkatkan panjang akar meskipun tidak berbeda nyata, yaitu terutama pada perlakuan penyiraman dan penyemprotan $P$. fluorescens P60 sebanyak 7 kali, dengan peningkatan sebesar $11.67 \%$ dibandingkan dengan kontrol.

Data bobot kering tanaman menunjukkan pengaruh nyata dibandingkan dengan kontrol. Berat kering tanaman tertinggi ditunjukkan pada perlakuan penyiraman dan penyemprotan $P$. fluorescens P60 sebanyak 5 dan 7 kali masing-masing sebesar $86.06 \mathrm{~g}$ dan $84.69 \mathrm{~g}$ atau terjadi peningkatan masingmasing sebesar $66.68 \%$ dan $66.15 \%$, jika dibandingkan dengan kontrol.

Hasil analisis data menunjukkan adanya perbedaan nyata antarperlakuan kontrol dengan pemberian antagonis terhadap waktu berbunga (Tabel 3). Waktu yang diperlukan tanaman untuk berbunga pertama kali lebih cepat pada tanaman yang diperlakukan dengan

Tabel 1 Hasil penyemprotan Pseudomonas fluorescens P60 terhadap komponen patosistem

\begin{tabular}{lcc}
\hline Perlakuan & Masa inkubasi (HST) & Intensitas penyakit* (\%) \\
\hline Kontrol & 24.85 & $59.32 \mathrm{a}$ \\
Insektisida** & 25.80 & $10.83 \mathrm{c}$ \\
Siram-semprot*** 1 kali & 26.50 & $33.47 \mathrm{~b}$ \\
Siram-semprot 2 kali & 24.05 & $35.11 \mathrm{~b}$ \\
Siram-semprot 3 kali & 28.83 & $21.32 \mathrm{bc}$ \\
Siram-semprot 5 kali & 33.20 & $15.88 \mathrm{bc}$ \\
Siram-semprot 7 kali & 27.87 & $15.95 \mathrm{bc}$ \\
\hline
\end{tabular}

*Angka yang diikuti huruf yang sama pada kolom yang sama menunjukkan tidak berbeda nyata pada BNJ 5\%. HST, hari setelah tanam.

**Insektisida Sipermetrin dosis $20 \mathrm{~mL}$ per $17 \mathrm{~L}$ air; *** P. fluorescens P60 konsentrasi $20 \mathrm{~mL}$ tanaman $^{-1}$ (untuk aplikasi 1-3) dan $40 \mathrm{~mL}$ tanaman $^{-1}$ (untuk aplikasi ke 4-7) 
penyiraman dan penyemprotan $P$. fluorescens P60 jika dibandingkan dengan kontrol dan bahkan dengan insektisida. Peningkatan kecepatan berbunga tanaman akibat perlakuan P. fluorescens P60 berkisar 24.02-25.98\% atau lebih cepat sekitar 5 hari.

Pada peubah hasil, aplikasi P. fluorescens P60 menunjukkan adanya perbedaan nyata. Bobot hasil semakin meningkat seiring bertambahnya frekuensi aplikasi antagonis. Bobot hasil tertinggi ditunjukkan pada perlakuan penyiraman $P$. fluorescens P60 sebanyak 5 kali atau terjadi peningkatan
53.157\% dibandingkan dengan kontrol (Tabel $3)$.

\section{Analisis Senyawa Fenol}

Analisis senyawa fenol tanaman cabai merah secara kualitatif menunjukkan pemberian perlakuan bakteri antagonis $P$. fluorescens P60 meningkatkan kandungan senyawa fenol di dalam jaringan tanaman. Hal ini tampak pada semua perlakuan $P$. fluorescens P60 jika dibandingkan dengan kontrol maupun dengan insektisida (Tabel 4).

Tabel 2 Hasil penyemprotan P. fluorescens P60 perlakuan terhadap populasi akhir antagonis

\begin{tabular}{lc}
\hline Perlakuan & Populasi akhir P. fluorescens P60 (upk/g) \\
\hline Kontrol & - \\
Insektisida* & - \\
Siram-semprot 1 kali** $^{*}$ & $3.70 \times 10^{10}$ \\
Siram-semprot $2 \mathrm{kali}^{* *}$ & $3.14 \times 10^{10}$ \\
Siram-semprot $3 \mathrm{kali}^{* *}$ & $6.68 \times 10^{11}$ \\
Siram-semprot $5 \mathrm{kali}^{* *}$ & $9.50 \times 10^{11}$ \\
Siram-semprot $7 \mathrm{kali}^{* *}$ & $10.60 \times 10^{11}$ \\
\hline
\end{tabular}

*Insektisida Sipermetrin dosis $20 \mathrm{~mL}$ per $17 \mathrm{~L}$ air; ** P. fluorescens $\mathrm{P} 60$ konsentrasi $20 \mathrm{~mL}$ tanaman ${ }^{-1}$ (untuk aplikasi 1-3) dan $40 \mathrm{~mL} \operatorname{tanaman}^{-1}$ (untuk aplikasi ke 4-7).

Tabel 3 Hasil penyemprotan P. fluorescens P60 terhadap pertumbuhan dan hasil tanaman cabai merah

\begin{tabular}{lcccccc}
\hline Perlakuan & $\begin{array}{c}\text { Tinggi } \\
\text { tanaman* } \\
(\mathrm{cm})\end{array}$ & $\begin{array}{c}\text { Panjang } \\
\text { akar } \\
(\mathrm{cm})\end{array}$ & $\begin{array}{c}\text { Bobot kering } \\
\text { tanaman* } \\
(\mathrm{g})\end{array}$ & $\begin{array}{c}\text { Bobot } \\
\text { kering akar } \\
(\mathrm{g})\end{array}$ & $\begin{array}{c}\text { Waktu } \\
\text { berbunga * } \\
(\mathrm{hst})\end{array}$ & $\begin{array}{c}\text { Bobot } \\
\text { hasil* } \\
\text { (g/tanaman })\end{array}$ \\
\hline Kontrol & $54.26 \mathrm{bc}$ & 33.37 & $28.67 \mathrm{~b}$ & 10.35 & $22.90 \mathrm{~b}$ & $698.89 \mathrm{~b}$ \\
Insektisida** & $58.20 \mathrm{abc}$ & 34.06 & $48.84 \mathrm{ab}$ & 12.70 & $22.55 \mathrm{~b}$ & $1124.68 \mathrm{ab}$ \\
Semprot $1 \mathrm{x}^{* * *}$ & $51.44 \mathrm{c}$ & 33.53 & $52.66 \mathrm{ab}$ & 11.82 & $17.25 \mathrm{a}$ & $935.42 \mathrm{ab}$ \\
Semprot $2 \mathrm{x}^{* * *}$ & $57.55 \mathrm{abc}$ & 32.50 & $55.41 \mathrm{ab}$ & 10.70 & $16.95 \mathrm{a}$ & $880.05 \mathrm{ab}$ \\
Semprot $3 \mathrm{x}^{* * *}$ & $66.40 \mathrm{abc}$ & 34.29 & $74.61 \mathrm{ab}$ & 12.29 & $16.95 \mathrm{a}$ & $1163.18 \mathrm{ab}$ \\
Semprot $5 \mathrm{x}^{* * *}$ & $71.12 \mathrm{a}$ & 35.67 & $86.06 \mathrm{a}$ & 13.48 & $17.40 \mathrm{a}$ & $1491.99 \mathrm{a}$ \\
Semprot $7 \mathrm{x}^{* * *}$ & $69.76 \mathrm{ab}$ & 37.78 & $84.69 \mathrm{a}$ & 13.40 & $16.95 \mathrm{a}$ & $1352.26 \mathrm{ab}$ \\
\hline
\end{tabular}

*Angka yang diikuti huruf yang sama pada kolom yang sama menunjukkan tidak berbeda nyata pada BNJ 5\%.

**Insektisida Sipermetrin dosis $20 \mathrm{~mL}$ per $17 \mathrm{~L}$ air; *** P. fluorescens $\mathrm{P} 60$ konsentrasi 20 mL tanaman ${ }^{-1}$ (untuk aplikasi 1-3) dan $40 \mathrm{~mL}_{\text {tanaman }}^{-1}$ (untuk aplikasi ke 4-7). 
Tabel 4. Hasil pengujian kandungan fenol pada penyemprotan P. fluorescens P60 dalam jaringan tanaman cabai merah

\begin{tabular}{lccc}
\hline \multirow{2}{*}{ Perlakuan } & \multicolumn{3}{c}{ Analisis jaringan } \\
\cline { 2 - 4 } & Saponin & Tanin & Glikosida \\
\hline Kontrol & + & + & + \\
Insektisida & ++ & + & + \\
Siram-semprot 1 kali & + & + & +++ \\
Siram-semprot 2 kali & ++ & + & ++ \\
Siram-semprot 3 kali & + & ++ & ++ \\
Siram-semprot 5 kali & +++ & +++ & +++ \\
Siram-semprot 7 kali & +++ & ++ & +++ \\
\hline,+ sedikit mengandung fenol; ++, cukup mengandung fenol; dan,+++ banyak mengandung fenol.
\end{tabular}

\section{PEMBAHASAN}

Gejala penyakit karena virus muncul pada semua tanaman cabai. Hal ini diduga P. fluorescens P60 membutuhkan waktu untuk beradaptasi pada lingkungan baru sehingga antagonis belum maksimum dalam mengimbas ketahanan tanaman. Yulianti (2009) melaporkan introduksi antagonis ke lingkungan yang baru sering kali kurang berhasil karena kurang mampu beradaptasi.

Tingginya intensitas penyakit pada perlakuan kontrol diduga karena tidak adanya usaha pengendalian baik pestisida maupun antagonis yang dapat mengendalikan perkembangan virus tanaman. Rendahnya intensitas penyakit pada perlakuan insektisida diduga karena zat aktif dalam insektisida dapat mengendalikan perkembangan hama vektor penular virus. Penyebaran virus dapat disebabkan adanya kontak dengan serbuk sari yang terinfeksi virus dan menempel di tanaman sehat, maupun infeksi karena vektor baik berupa nematoda, cendawan, gulma, dan hama (Jones 2009).

Antagonis P. fluorescens P60 yang telah beradaptasi mampu mengoloni akar tanaman sehingga merangsang tanaman untuk meningkatkan produksi senyawa metabolit sekunder yang berperan dalam ketahanan tanaman (Soesanto et al. 2011). Hal ini diperkuat oleh pendapat Maqqon et al. (2006) dan Soesanto et al. (2010). Semakin tinggi kandungan fenol maka semakin meningkat ketahanan terimbas tanaman dalam menahan serangan patogen (Treutter 2005; Witzell dan Martín 2008). Hal ini terbukti dari hasil analisis jaringan yang menunjukkan peningkatan senyawa fenol akibat pemberian P. fluorescens P60.

Pemberian bakteri antagonis $P$. fluorescens P60 secara berkala diduga mampu mengoloni perakaran dan berpengaruh efektif sebagai rizobakteri pemacu pertumbuhan tanaman (PPT) yang ditunjukkan oleh tingginya populasi antagonis tersebut. Wardhana et al. (2009) dan Soesanto et al. (2010) menyatakan bahwa bakteri P. fluorescens P60 dapat menguntungkan pada perkembangan dan pertumbuhan tanaman sebagai rizobakteri PPT. Hal ini ditunjukkan dengan adanya peningkatan tinggi tanaman dan kecenderungan peningkatan panjang akar.

Antagonis $P$. fluorescens P60 menghasilkan IAA yang berperan sebagai pendukung pertumbuhan sehingga mampu untuk meningkatkan bobot kering tanaman. Hal ini sesuai dengan pernyataan Soesanto et al. (2011) bahwa P. fluorescens P60 mampu menghasilkan IAA yang mampu mendukung pertumbuhan tanaman.

Bobot kering tanaman yang rendah pada perlakuan kontrol diduga karena infeksi virus yang tinggi menyebabkan proses fisiologi tanaman cabai merah menjadi terganggu. Hal ini sesuai dengan pendapat Whenham dan 
Fraser (1990) bahwa virus dapat mengubah pertumbuhan dan perkembangan tanaman. Aktivitas auksin dan giberelin secara umum menurun akibat infeksi virus tanaman. Kondisi ini akan mengganggu proses fisiologi tanaman dan akan menimbulkan kerusakan yang dapat menghambat pertumbuhan dan perkembangan tanaman. Selain itu, tingginya infeksi virus patogen pada tanaman kontrol membuktikan bahwa tanaman cabai rentan terhadap serangan virus.

Tidak adanya perbedaan bobot kering akar tanaman menunjukkan bahwa $P$. fluorecens P60 belum mampu meningkatkan bobot kering akar tanaman, meskipun ada kecenderungan peningkatan berat kering akar tanaman pada perlakuan. Hal ini diduga antagonis belum maksimum dalam meningkatkan berat kering akar tanaman karena virus yang menginfeksi tanaman cabai mengganggu proses fisiologis sehingga akar tanaman tidak tumbuh dan berkembang secara optimum. Hal ini sesuai dengan pendapat Whenham dan Fraser (1990) dan Yang et al. (2007), yang menyebutkan bahwa infeksi virus mosaik tembakau meningkatkan kandungan asam absisat dan laju metabolismenya, yang akan berakibat kepada terhambatnya pertumbuhan tanaman sehat karena menurunnya fungsi akar.

Antagonis mampu mempercepat waktu berbunga tanaman cabai. $P$. fluorescens P60 diduga dapat meningkatkan beberapa produksi hormon di dalam tubuh tanaman. Hal ini sesuai dengan pendapat Landa et al. (2002) dan Soesanto et al. (2011) bahwa $P$. fluorescens dapat menghasilkan hormon, di antaranya auksin, giberelin, dan sitokinin. Virus yang menginfeksi pertanaman menghambat perkembangan tanaman dalam pembungaan. Hal ini sesuai dengan pendapat Jones (2009) bahwa virus memengaruhi proses fisiologis dan biokimiawi serta anatomi yang menyebabkan perubahan pada berbagai stadium pertumbuhan dan perkembangan tanaman.

Tingginya berat hasil selaras dengan tingginya berat kering tanaman dan rendahnya intensitas penyakit, yang membuktikan bahwa antagonis $P$. fluorescens P60 mampu menekan perkembangan patogen. Antagonis mampu memacu pertumbuhan tanaman dan juga dapat meningkatnya ketahanan terimbas tanaman (Soesanto et al. 2011).

Semua perlakuan penyiraman dan penyemprotan dengan $P$. fluorescens P60 mampu meningkatkan kandungan saponin, tanin, dan glikosida tanaman cabai. Hal ini menunjukkan bahwa $P$. fluorescens P60 memiliki kemampuan mengimbas ketahanan tanaman terhadap penyakit secara kimiawi, yaitu dengan meningkatkan senyawa fenol tanaman, yang sesuai dengan hasil penelitian Soesanto et al. (2010, 2011). Hal ini selaras dengan pendapat Taufik et al. (2005) yang mengatakan bahwa konsentrasi asam salisilat dan enzim peroksidase relatif lebih tinggi pada tanaman cabai yang diperlakukan dengan PGPR dibandingkan dengan tanpa PGPR.

\section{UCAPAN TERIMA KASIH}

Penelitian ini merupakan bagian dari penelitian utama yang didanai Hibah Kompetensi Batch III TA 2011, Direktorat Jenderal Perguruan Tinggi, untuk itu diucapkan terima kasih. Terima kasih juga disampaikan kepada Hilda Mustikarini Deviananda dan C. Basir yang telah membantu secara teknis dalam penelitian ini.

\section{DAFTAR PUSTAKA}

Chairul. 2003. Identifikasi secara cepat bahan bioaktif pada tumbuhan di lapangan. Berita Biol. 6(4):621-630.

Dolores LM. 1996. Management of Pepper Viruses. Di dalam: Proceeding on the AVNET II. Final Workshop Philippines; 1995 Feb 21-25. Manila (PH) AVRDC. hlm 334-342.

Elad Y, Chet I, Baker R. 1987. Increased growth response of plants induced by rhizobacteria antagonistic to soilborne pathogenic fungi. Plant Soil. 98(3):325330. DOI: http://dx.doi.org/10.1007/ BF02378353.

Jones RAC. 2009. Plant virus emergence and evolution: Origins, new encounter scenarios, factors driving emergence, effects of changing world conditions, 
and prospects for control. Virus Res. 141(2):113-130. DOI: http://dx.doi. org/10.1016/j.virusres.2008.07.028.

Landa BB, de WerdHenricus AE, McSpadden Gardener BB, Weller DM. 2002. Comparison of three methods for monitoring populations of different genotypes of 2,4-diacethylphloroglucinolproducing Pseudomonas fluorescens in rhizosphere. Phytopathology. 92:129137. DOI: http://dx.doi.org/10.1094/ PHYTO.2002.92.2.129.

Maqqon M, Kustantinah, Soesanto L. 2006. Penekanan hayati penyakit layu Fusarium tanaman cabai merah. Agrosains. 8(1):50 56.

Soesanto L, Mugiastuti E, Rahayuniati RF. 2010. Kajian mekanisme antagonis Pseudomonas fluorescens P60 terhadap Fusarium oxysporum f. sp. lycopersici pada tanaman tomat in vivo. J Hama Penyakit Tumbuhan Trop. 10(2):108-115.

Soesanto L, Mugiastuti E, Rahayuniati RF. 2011. Biochemical characteristic of Pseudomonas fluorescens P60. J Biotechnol Biodiver. 2:19-26.

Taufik M, Hidayat SH, Suastika G, Sumaraw SM, Sujiprihati S. 2005. Evaluation of plant growth promoting rhizobacteria as a protecting agent against Cucumber Mosaic Virus and Chilli Veinal Mottle Virus on chilli pepper. Hayati. 12(4):139-144.

Treutter D. 2005. Significance of Flavonoids in Plant Resistance and Enhancement of Their Biosynthesis. Plant Biol. 7(6):581-591.
DOI: http://dx.doi.org/10.1055/s-2005-87 3009.

Wardhana DW, Soesanto L, Utami DS. 2009. Penekanan hayati penyakit layu Fusarium pada subang gladiol. J Hort. 19(2):304311.

Whenham RJ, Fraser RSS. 1990. Plant growth regulators, viruses and plant growth. Recognition and Response in Plant-Virus Interactions. NATO ASI Series. 41:287310. DOI: http://dx.doi.org/10.1007/9783-642-74164-7_15.

Witzell J, Martín JA. 2008. Phenolic metabolites in the resistance of northern forest trees to pathogens - past experiences and future prospects. Can J Forest Res. 38(11):2711-2727. DOI: http:// dx.doi.org/10.1139/X08-112.

Yang K-S, Kim H-S, Jin U-H, Lee, SS, Park J-A, Lim YP, Pai H-S. 2007. Silencing of NbBTF3 results in developmental defects and disturbed gene expression in chloroplasts and mitochondria of higher plants. Planta. 225(6): 1459-1469. DOI: http://dx.doi.org/10.1007/s00425-0060453-3.

Yulianti T. 2009. Pengelolaan patogen tular tanah untuk mengembalikan kejayaan tembakau Temanggung di Kabupaten Temanggung. Perspektif. 8(1):1-16. 